\title{
Penerapan Fuzzy Time Series Dalam Peramalan Nilai KWH Listrik Golongan Tarif Rumah Tangga di Jawa Timur
}

\author{
Ekky Hidma Octia Rahmah dan Mohammad Isa Irawan \\ Departemen Matematika, Fakultas Matematika, Komputasi, dan Sains Data, \\ Institut Teknologi Sepuluh Nopember (ITS) \\ e-mail:mii@its.ac.id
}

\begin{abstract}
Abstrak-Listrik telah menjadi kebutuhan utama manusia untuk menjalankan segala aktifitasnya. Akan tetapi, peningkatan kebutuhan itu tidak sebanding dengan peningkatan penyediannya yang berakibat sering terjadi pemadaman aliran listrik. Kondisi tersebut mendukung dilakukannya pengembangan penyediaan tenaga listrik dengan melakukan peramalan nilai kebutuhan energi listrik dengan menggunakan data pemakaian $\mathrm{kWh}$ listrik jenis golongan tarif rumah tangga dengan metode fuzzy time series. Hasilnya adalah metode fuzzy time series baik digunakan pada data pemakaian $\mathrm{kWh}$ listrik kelompok rumah tangga golongan tarif reguler, karena rata-rata nilai MAPE yang dihasilkan sebesar $19 \%$ atau dapat dikatan rata-rata ketepatan nilainya sebesar $81 \%$, terutama untuk data jenis golongan tarif $R-3 / 6.600 \mathrm{VA}$ ke atas dengan nilai MAPE sebesar 4,8 persen atau dapat dikatakan ketepatan nilainya 95,2 \%.
\end{abstract}

Kata Kunci-Peramalan, Fuzzy Time Series, KWH Listrik, Golongan Tarif Rumah Tangga.

\section{PENDAHULUAN}

$\mathrm{L}$ ISTRIK merupakan salah satu bentuk energi yang sangat penting bagi kehidupan manusia. Setiap hari listrik digunakan hampir pada setiap aspek kehidupan. Pada kenyataanya, kebutuhan listrik akan semakin meningkat seiring dengan berkembangnya bidang teknologi dan informasi. Berdasarkan data pada Buku Statistik Ketenaga Listrikan No. 29 - 2016, Jawa Timur merupakan daerah dengan jumlah penjualan listrik di peringkat ketiga dari 35 provinsi di Indonesia. Dari data tersebut, dapat dikatakan bahwa Jawa Timur termasuk ke dalam daerah dengan tingkat kebutuhan listrik yang tinggi [1]. Manajer Komunikasi Hukum dan Administrasi PLN Distribusi Jawa Timur, Wisnu Yulianto mengatakan bahwa kenaikan konsumsi listrik di wilayah Jawa Timur dikarenakan mulai berkembangnya perekonomian masyarakat pada wilayah setempat. Pelanggan terbesar PLN Jawa Timur adalah rumah tangga yang mencapai 9.778 .949 pelanggan atau 91 persen dari jumlah total pelanggan di Jawa Timur [2].

Akan tetapi, kecenderungan pada saat ini, peningkatan kebutuhan energi listrik, tidak sebanding dengan peningkatan penyediaan energi listrik. Akibatnya, sering terjadi pemadaman aliran listrik, khususnya pada jam-jam beban puncak, yaitu akibat beban pemakaian melebehi daya yang tersedia. Kondisi ini mendukung dilakukannya pengembangan penyediaan tenaga listrik untuk rentang waktu selanjutnya [3]. Salah satu cara yang bisa dilakukan adalah dengan memprediksi nilai kebutuhan listrik di waktu mendatang dengan melihat data konsumsi listrik pada rentang waktu sebelumnya. Selain memprediksi kebutuhan listrik, data konsumsi listrik pada rentang waktu sebelumnya dapat digunakan untuk memprediksi jumlah nilai penjualan energi listrik dengan menggunakan nilai tarif dasar listrik yang telah ditetapkan dalam Peraturan Menteri Energi dan Sumber Daya Mineral Republik Indonesia No. 28 Tahun 2016 berdasarkan golongan tariff [4]. Pada Studi ini dilakukan penelitian tentang peramalan terhadap nilai kwh listrik di Jawa Timur, dengan data konsumsi energi listrik bulanan per golongan tarif rumah tangga yang diperoleh dari PT. PLN Persero, Distribusi Jawa Timur dengan menggunakan metode Fuzzy Time Series.

\section{DASAR TEORI}

\section{A. Data Time Series}

Menurut Dedi Rosadi, untuk dapat memahami pemodelan runtun waktu, perlu diketahui beberapa jenis data berdasarkan waktu. Salah satunya adalah time series (runtun waktu) data, yaitu jenis data yang dikumpulkan menurut urutan waktu dalam suatu rentang waktu tertentu. Jika waktu dipandang bersifat diskrit (waktu dapat dimodelkan bersifat kontinu), frekuensi pengumpulan selalu sama (equidistant). Dalam kasus diskrit, frekuensi dapat berupa detik, menit, jam, hari, minggu, bulan, atau bahkan tahun [5]. Data runtut waktu yang terdiri dari variable tunggal (single variable) dinamakann sebagai univariate, sedangkan yang berisi lebih dari satu variabel dinamakan multivariate.

\section{B. Deskripsi Umum PT. PLN (Persero), Distribusi Jawa Timur}

Wilayah usaha PT. PLN Persero, Distribusi Jawa Timur dibagi menjadi 16 daerah pelayanan yang melayani wilayah administrasi propinsi Jawa Timur, yaitu Area Surabaya Selatan, Surabaya Utara, Surabaya Barat, Malang, Pasuruan, Kediri, Mojokerto, Madiun, Jember, Bojonegoro, Banyuwangi, Pamekasan, Situbondo, Gresik, Sidoarjo, dan Ponorogo.

Pengelompokan data yang berlaku di PT. PLN (Persero), Distribusi Jawa Timur, diantaranya berdasarkan [6].

1. Pembangkit, data pembangkit terdiri atas PLTM (Pusat Listrik Tenaga Mikrohidro) dan PLTD (Pusat Listrik Tenaga Diesel) Skala Kecil.

2. Pelanggan, data pelanggan diuraikan menurut golongan tarif sesuai dengan Surat Keputusan Direksi PT. PLN Persero, Distribusi Jawa Timur No.336.K/010/DIR/2003 tanggal 31 Desember 2003.

3. Menurut Jenis Pelanggan, dibagi menjadi:

a. Kelompok Rumah Tangga adalah penjumlahan Golongan Tarif R-1, R-2, dan R-3.

b. Kelompok Bisnis adalah penjumlahan Golongan Tarif B-1, B-2, B-3, Traksi(T), Curah(C), dan lainnya(L). 
c. Kelompk Industri adalah penjumlahan Golongan Tarif I-1, I-2, I-3, dan I-4.

d. Kelompok Sosial adalah penjumlahan Golongan Tarif S-1, S-2 dan S-3.

e. Kelompok Publik adalah penjumlahan Golongan Tarif P-1 dan P-2.

f. Kelompok Penerangan Jalan Umum adalah Golongan Tarif P-3.

\section{Himpunan Fuzzy}

Diberikan $U$ sebagai universe of discourse. Sebuah himpunan fuzzy A pada $U$ dapat didefinisikan sebagai berikut [7],

$$
A=\left\{\left(u_{i}, \mu_{A}\left(u_{i}\right)\right) \mid u_{i} \in U\right\}
$$

Dimana $\mu_{A}$ merupakan fungsi keanggotaan dari A, atau dapat dinotasikan sebagai $\mu_{A}: U \rightarrow[0,1]$, dan $\mu_{A}\left(u_{i}\right)$ merupakan derajat keanggotan dari elemen $u_{i}$ dalam himpunan fuzzy A. Jika $U$ didefinisikan sebagai himpunan berhingga (anggota himpunan fuzzy bernilai diskrit), maka A dapat ditulis sebagai [7]:

$$
A=\sum \frac{\mu_{A}\left(u_{i}\right)}{u_{i}}=\frac{\mu_{A}\left(u_{1}\right)}{u_{1}}+\frac{\mu_{A}\left(u_{2}\right)}{u_{2}}+\frac{\mu_{A}\left(u_{3}\right)}{u_{3}}+\cdots+\frac{\mu_{A}\left(u_{n}\right)}{u_{n}} .
$$

Sri Kusumadewi dan Hari Purnomo (2004), dalam bukunya menjelaskan bahwa himpunan fuzzy merupakan perluasan dari himpunan klasik (crisp). Pada himpunan klasik A, jika x merupakan anggota dari himpunan A, maka derajat keanggotaan dari $x$ tersebut adalah 1 atau dapat ditulisakan sebagai $\mu_{A}(x)=1$, sedangkan jika $\mathrm{x}$ bukan anggota dari himpunan $\mathrm{A}$, maka derajat keanggotaan dari $x$ adalah 0 atau dapat dituliskan sebagai $\mu_{A}(x)=0$. Himpunan fuzzy memiliki dua atribut, yaitu [8]:

1. Linguistik, yaitu penamaan suatu grup yang mewakili suatu keadaan atau kondisi tertentu dengan menggunakan bahasa alami, seperti : muda, paruhbaya, tua.

2. Numeris, yaitu suatu nilai (angka) yang menunjukkan ukuran dari suatu variable, seperti 40, 25, 50, dsb.

\section{Konsep Fuzzy Time Series}

Dalam konsep fuzzy time series terdapat beberapa definisi sebagai berikut [9],

\section{Definisi 1. Fuzzy Time Series}

Diberikan $Y(t)(t=0,1,2, \ldots)$, sebuah subset dari bilangan riil sebagai semesta pembicara pada himpunan fuzzy $f_{i}(t)(i=1,2, \ldots)$ yang terdefinisi. Jika $F(t)$ merupakan kumpulan dari $f_{i}(t)(i=1,2, \ldots)$, maka $F(t)$ dinamakan fuzzy time series pada $Y(t)$. Untuk itu, $F(t)$ dapat dipahami sebagai sebuah variable linguistik time series, dimana $f_{i}(t)(i=1,2, \ldots)$, adalah nilai linguistik pada $F(t)$.

\section{Definisi 2. Relasi Fuzzy}

Jika terdapat sebuah relasi fuzzy $R(t-1, t)$, sehingga $F(t)=F(t-1) \circ R(t-1, t)$, maka $F(t)$ dikatakan terjadi karena $F(t-1)$ dan dinotasiskan sebagai :

$$
F(t-1) \rightarrow F(t) \text {. }
$$

Definisi 3. Model Orde Pertama dari Fuzzy Time Series

Jika dikatakan $F(t)$ terjadi karena $F(t-1)$ dinotasikan dengan $F(t-1) \rightarrow F(t)$, maka relasi ini dapat direpresentasikan sebagai :

$$
F(t)=F(t-1) \circ R(t-1, t),
$$

dimana $R(t-1, t)$ adalah sebuah relasi fuzzy antara $F(t)$ dan $F(t-1)$, serta dapat dikatakan pula sebagai model orde pertama dari $F(t)$.

\section{Definisi 4. FLR (Fuzzy Logical Relationship)}

Diberikan $F(t-1)=A_{i}$ dan $F(t)=A_{j}$. Hubungan antara kedua data yg consecutive (berurutan) dinamakan FLR. Seperti contoh, $F(t)$ dan $F(t-1)$, dapat dinotasikan sebagai

$$
A_{i} \rightarrow A_{j} \quad \ldots(1),
$$

dimana $i, j=1,2, \ldots, p, A_{i}$ dinamakan left hand side (LHS) dan $A_{j}$ right hand side (RHS) pada FLR.

Definisi 5. FLRG (Fuzzy Logical Relationship Group)

Diberikan $A_{i} \rightarrow A_{j}, A_{i} \rightarrow A_{k}, \ldots, A_{i} \rightarrow A_{p}$ adalah FLR dengan LHS yang sama sehingga dapat dikelompokkan menjadi FLRG yang terurut dengan meletakkan seluruh RHS dalam FLR bersama pada RHS dalam FLRG. Atau dapat ditulis sebagai :

$$
A_{i} \rightarrow A_{j}, A_{k}, \ldots, A_{p}
$$

dimana $i, j, k, \ldots, p$ merupakan representasi dari bilangan bulat positif lebih dari nol.

\section{E. Peramalan Fuzzy Time Series}

Prosedur peramalan yang dikembangkan oleh Riswan, Zuhaimy, dan Mustofa dibagi menjadi beberapa tahap, diantaranya [7] :

\section{Universe of Discourse (Semesta Pembicaraan)}

Mendefinisikan universe of discourse (semesta pembicaraan) dengan membagi data menjadi beberapa interval/partisi dengan menggunakan persamaan

$$
U=\left[D_{\min }-D_{1}, D_{\max }+D_{2}\right]
$$

dimana $D_{\min }$ dan $D_{\max }$ merupakan nilai minimal dan maksimal pada keseluruhan data, serta $D_{1}$ dan $D_{2}$ merupakan sembarang bilangan positif sehingga batas bawahnya lebih kecil dari $D_{\min }$ dan batas atasnya lebih besar dari $D_{\max }$, seperti yang umum digunakan pada data kelompok. Akan tetapi, perubahan pada nilai $D_{1}$ dan $D_{2}$ di tiap data yang digunakan dapat mengubah nilai hasil akhir ramalan.

Kemudian $U$ dipartisi menjadi $\mathrm{p}$ interval yang sama, $u_{1}, u_{2}, \ldots, u_{p},(p<n)$ dengan panjang 1. Kemudian diterapkan pendekatan Sturges. Herbert Sturges meninjau sebuah histogram frekuensi dengan $k$ kelompok dimana kelompok ke $-i$ dapat diperoleh dengan menggunakan koefisien binomial $\left(\begin{array}{c}k-1 \\ i\end{array}\right), \quad i=0,1, \ldots, k-1$. Dengan meningkatnya nilai $k$, histogram frekuensi akan mendekati bentuk kepadatan normal (normal density). Total ukuran sampel dirumuskan dengan ekspansi (perluasan) binomial [18] sebagai berikut,

$$
n=\sum_{i=0}^{k-1}\left(\begin{array}{c}
k-1 \\
i
\end{array}\right)=(1+1)^{k-1}=2^{k-1},
$$

sehingga, jumlah kelas yang akan dipilih untuk membangun sebuah histogram adalah

$$
p=1+3,3 \log (n) \ldots
$$

dan

$$
2^{p}<n^{2}
$$

dengan $p$ adalah jumlah interval dan $n$ adalah jumlah data pengamatan[6]. 


\section{Himpunan Fuzzy}

Membentuk himpunan fuzzy pada pengamatan. Setiap pengamatan linguistik $A_{i}$ dapat didefinisikan oleh interval $u_{1}, u_{2}, \ldots, u_{p} . \quad$ Setiap $\quad A_{i}, i=1,2, \ldots, p \quad$ dapat direpresentasikan seperti persamaan :

$$
A_{i}=\sum_{j=1}^{p} \frac{k_{j}}{u_{j}}
$$

dan nilai $k_{j}$ ditentukan oleh :

i). jika $j=i-1$, maka $k_{j}=0.5$;

ii). jika $j=i$, maka $k_{j}=1$;

iii). jika $j=i+1$, maka $k_{j}=0,5$; selain itu $k_{j}=0$.

\section{Fuzzy Logical Relation (FLR)}

Menentukan relasi logika fuzzy (FLR) berdasarkan pada data fuzzy time series $A_{i} \rightarrow A_{1}, A_{2}, \ldots, A_{p}$ dimana relasi logika fuzzy " $A_{i} \rightarrow A_{j}$ " yang berarti "jika data fuzzy time series pada waktu $(t-1)$ adalah $A_{i}$, maka data fuzzy time series pada waktu $t$ adalah $A_{j}$ ".

\section{Fuzzy Logical Relation Group (FLRG)}

Menentukan grup logika fuzzy ke dalam trend yang sesuai. FLR dengan LHS yang sama dapat dikelompokkan menjadi sebuah FLRG.

\section{Pembobotan pada FLRG dan Defuzzifikasi}

Faktor pembobotan dinotasikan dalam matriks bobot yang diberikan dalam definisi berikut [10]:

Definisi 6. Sebuah operator OWA didefinisikan sebagai berikut [11]:

$$
\mu_{O W A}(x)=\sum_{j} w_{j} \mu_{j}(x)
$$

dimana $w=\left\{w_{1}, \ldots, w_{n}\right\}$ adalah sebuah vector dari bobot $w_{i}$ dengan $w_{i} \in[0,1]$ dan $\sum_{i} w_{i}=1$, dan $\mu_{j}(x)$ adalah nilai keanggotaan terbesar $\mathrm{ke}-\mathrm{j}$ untuk $x$ dimana derajat keanggotaannya telah ditentukan.

Pemberian bobot didasarkan pada nilai indeks dari relasi terdekat pada FLRG. Pembobotan pada FLRG diberikan berdasarkan table berikut [7]:

Tabel 1.

Kemungkinan nilai indeks yang terjadi pada FLRG [7]

\begin{tabular}{ccc}
\hline \hline No & FLRG & Nilai Index \\
\hline 1 & $A_{i} \rightarrow A_{(j-1)}, A_{j}, A_{(j+1)}$ & {$[(j-1), j,(j+1)]$} \\
2 & $A_{i} \rightarrow A_{(j-1)}, A_{(j+1)}, A_{j}$ & {$[(j-1),(j+1), j]$} \\
3 & $A_{i} \rightarrow A_{(j+1)}, A_{j}, A_{(j-1)}$ & {$[(j+1), j,(j-1)]$} \\
4 & $A_{i} \rightarrow A_{(j+1)}, A_{(j-1)}, A_{j}$ & {$[(j+1),(j-1), j]$} \\
5 & $A_{i} \rightarrow A_{j}, A_{(j-1)}, A_{(j+1)}$ & {$[j,(j-1),(j+1)]$} \\
6 & $A_{i} \rightarrow A_{j}, A_{(j+1)}, A_{(j-1)}$ & {$[j,(j+1),(j-1)$} \\
7 & $A_{i} \rightarrow A_{(j-1)}, A_{j}$ & {$[(j-1), j]$} \\
8 & $A_{i} \rightarrow A_{j}, A_{(j+1)}$ & {$[j,(j+1)]$} \\
9 & Yang lain. & {$[0]$} \\
\hline \hline
\end{tabular}

Contoh $1:$ andaikan, $A_{i} \rightarrow A_{(j-1)}, A_{j}, A_{(j+1)}$ adalah sebuah FLRG dimana $(j-1), j,(j+1)$ merupakan nilai index terdekat dari kiri dan kanan sisi $A_{i}, i=j, i, j \geq 2$ dan $i, j \in$ $Z$. Dengan menggunakan index tersebut, perhitungan nilai bobot dapat dirumuskan sebagai

$$
\begin{aligned}
& W\left(A_{i}\right)=\frac{\text { nilai indeks }}{\text { total dari nilai indeks }} \\
& W\left(A_{i}\right)=\left[\frac{(j-1)}{(j-1)+j+(j+1)} \frac{j}{(j-1)+j+(j+1)} \frac{(j+1)}{(j-1)+j+(j+1)}\right]
\end{aligned}
$$

Misalkan $(j-1)=c_{1}, \mathrm{j}=c_{2}$, dan $(j+1)=c_{3}$, persamaan (6) dapat dibentuk kembali menjadi

$W\left(A_{i}\right)=\left[\begin{array}{lll}\frac{c_{1}}{c_{1}+c_{2}+c_{3}} & \frac{c_{2}}{c_{1}+c_{2}+c_{3}} \frac{c_{3}}{c_{1}+c_{2}+c_{3}}\end{array}\right]$

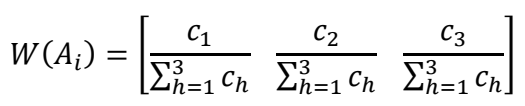

Dimana $\sum W_{h}\left(A_{i}\right)=\frac{\sum_{h=1}^{3} c_{h}}{\sum_{h=1}^{3} c_{h}}=1$ memenuhi kondisi definisi 6. Selanjutnya setiap bobot elemen dapat direpresentasikan dalam bentuk matriks $\boldsymbol{W}$ seperti berikut :

$$
\boldsymbol{W}\left(A_{i}\right)=\left[w_{1} w_{2} w_{3}\right]
$$

Dan untuk menghitung hasil peramalan, dilakukan pemberian operator product matrix $(\times)$ antara matriks defuzzifikasi dengan matriks transpose pembobotan $\boldsymbol{W}\left(A_{i}\right)^{T}$, seperti pada contoh 1, didapatkan matriks defuzzifika yang merupakan nilai tengah dari $A_{(j-1)}, A_{j}, A_{(j+1)}$ :

$$
\boldsymbol{M}\left(A_{i}\right)=\left[m_{A(j-1)} m_{A(j)} m_{A(j+1)}\right]
$$

atau dapat ditulis sebagai

$$
\widehat{A}=\boldsymbol{M}\left(A_{i}\right) \times \boldsymbol{W}\left(A_{i}\right)^{T}
$$

6. Peramalan Numerik

Meramalkan nilai numerical time series, dengan menggunakan dua aturan berikut :

Rule 1: Jika tidak terdapat bobot pada FLRG maka nilai peramalan sama dengan rata-rata dari nilai tengah interval pada nilai linguistic time series.

Rule 2: Selain itu, akan digunakan persamaan (8) sebagai nilai peramalan.

\section{Hasil Akhir Peramalan}

Dalam analisis time series, nilai beda pertama dapat dituliskan sebagai hasil selisih antara data aktual waktu $t$ atau $X_{t}$ dan data aktual pada waktu $(t-1)$ atau $X_{(t-1)}$. Sehingga nilai beda pertama dapat dituliskan sebagai berikut[7],

$$
\Delta^{1} d=X_{t}-X_{(t-1)}
$$

Persamaan (9) tersebut digunakan untuk menghilangkan trend pada data. Persamaan tersebut juga digunakan supaya hasil peramalan lebih tepat dan mencegah nilai hasil yang sama pada tiap periode ramalannya [7].

Sehingga, hasil akhir peramalan dapat dirumuskan sebagai,

$$
F(t)=\hat{A}+X_{t}-X_{(t-1)}
$$

dengan keterangan :

$F(t) \quad=$ hasil ramalan waktu $t$,

$\hat{A} \quad=$ nilai transformasi $A_{i}$,

$X_{t} \quad=$ data aktual pada waktu $t$,

$X_{(t-1)}=$ data aktual pada waktu $(t-1)$.

\section{F. Nilai Akurasi}

Ukuran ketepatan peramalan dipandang sebagai kriteria penolakan untuk memilih suatu metode peramalan sehingga dapat digunakan untuk menentukan metode yang lebih baik [12]. Suatu model deret waktu dikatakan baik apabila hasilnya telah sesuai atau mendekati dengan kenyataan. Dengan kata lain, apabila kesalahan (error) model semakin kecil dan nilai akurasinya tinggi, maka model bisa dikatakan baik. Mean Absolute Percentage Error (MAPE) dihitung dengan menggunakan kesalahan mutlak dalam setiap periode kemudian dibagi dengan nilai yang diamati sesuai dengan periode tersebut, kemudian persen dari hasil tersebut dibagi sebanyak data yang diamati. MAPE dapat dinotasikan sebagai berikut [13]:

MAPE $=\frac{1}{n} \sum \frac{\mid \text { Actual }- \text { Forecast } \mid}{\text { Actual }} \times 100$ 
Dengan keterangan, Actual merupakan data nilai konsumsi KWH listrik yang diamati, Forecast merupakan hasil nilai peramalan konsumsi KWH listrik yang diamati, serta $n$ merupakan jumlah data yang diamati. Nilai MAPE digunakan untuk menganalisis kinerja proses prediksi seperti yang tertera pada Tabel 2 [14].

Tabel 2.

Nilai MAPE untuk mengevaluasi nilai ramalan [14]

\begin{tabular}{cc}
\multicolumn{2}{c}{ Nilai MAPE untuk mengevaluasi nilai ramalan [14] } \\
\hline \hline Nilai MAPE & Akurasi Prediksi \\
\hline MAPE $\leq 10 \%$ & Tinggi \\
$10 \%<$ MAPE $\leq 20 \%$ & Baik \\
$20 \%<$ MAPE $\leq 50 \%$ & Reasonable \\
MAPE $>50 \%$ & Rendah. \\
\hline \hline
\end{tabular}

\section{II.METODOLOGI PENELITIAN}

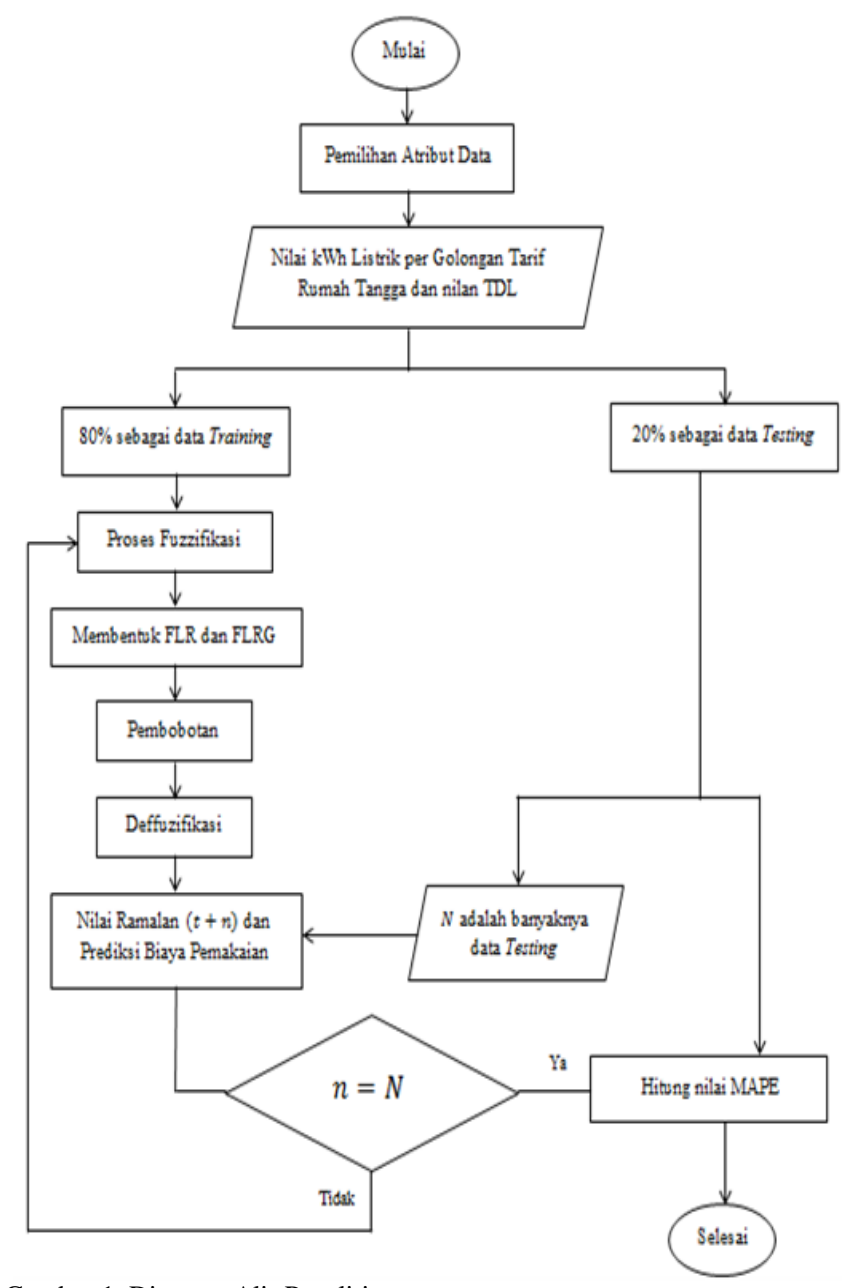

Gambar 1. Diagram Alir Penelitian.

Data yang digunakan dalam penulisan Studi ini adalah data konsumsi energi listrik berupa total nilai konsumsi listrik bulanan jenis golongan tarif rumah tangga dimulai dari bulan Januari 2013 sampai dengan bulan Maret 2018 dalam satuan KWH (Kilo Watt Hour) yang diperoleh dari PLN Distribusi Jawa Timur, serta informasi tentang tarif dasar listrik yang telah ditetapkan dalam Peraturan Menteri Energi dan Sumber Daya Mineral Republik Indonesia No. 28 Tahun 2016. Data pemakian kWh listrik yang digunakan dalam studi ini berasal dari data laporan penjualan listrik (laporan 309) PLN Distribusi Jawa Timur, dimana file laporan tersebut berbentuk data excel, yang berisi banyak atribut, mulai dari jumlah pelanggan, jumlah daya terpasang, jumlah pemakaian $\mathrm{kWh}$ listrik, sampai dengan total rupiah penjualan. Dari data tersebut dilakukan pemilihan atribut yang sesuai yaitu, periode penjualan (bulan) serta jumlah nilai pemakaian $\mathrm{kWh}$ listrik, yang kemudian disimpan pada file excel lain dengan nama baru (.xlsx) sesuai dengan jenis golongan tarif rumah tangga. Kemudian, dilakukan peramalan data nilai pemakaian $\mathrm{kWh}$ listrik dengan metode fuzzy time series menggunakan software Matlab 2013. Diagram alir penelitian akan ditampilkan pada Gambar 1.

\section{HASIL DAN PEMBAHASAN}

Sebelum meramalkan suatu data, suatu metode harus dilakukan pengujian agar dapat diketahui kemampuan penggunan dari metode tersebut. Sehingga, pada pembahasan Studi ini, tiap data nilai pemakaian $\mathrm{kWh}$ listrik per jenis golongan tarif rumah tangga akan dibagi menjadi dua yaitu, sebanyak $80 \%$ dari data digunakan sebagai data latih (training) dan sebanyak 20\% digunakan sebagai data uji (testing). Dalam paper ini, akan ditunjukkan satu contoh menggunakan data pemakaian $\mathrm{kWh}$ listrik kelompok rumah tangga jenis golongan tariff R-1/450 VA.

Data awal yang digunakan untuk data training adalah data pemakaian $\mathrm{kWh}$ listrik golongan tarif R-1/450 VA yang berjumlah 51 data. Dan sebagai data testing, data yang digunakan adalah data pemakaian $\mathrm{kWh}$ listrik golongan tarif R-1/450 VA berjumlah 12 data. Tarif dasar listrik yang berlaku adalah Rp. 415 ,- per $\mathrm{kWh}$. Nilai $\mathrm{D}_{1}$ dan $\mathrm{D}_{2}$ yang digunakan, masing - masing adalah 1.000.000.

Hasil dari proses fuzzifikasi di dapatkan, universe of discourse U dari data training adalah [239756746 292577240]. Dengan selang yang terbentuk adalah 7 , sehingga selang interval yang terbentuk adalah sebagai berikut,

$$
\begin{aligned}
& \mathrm{u}_{1}=[239756746-247302530] \\
& \mathrm{u}_{2}=[247302531-254848315] \\
& \mathrm{u}_{3}=[254848316-262394100] \\
& \mathrm{u}_{4}=[262394101-269939885] \\
& \mathrm{u}_{5}=[269939890-277485670] \\
& \mathrm{u}_{6}=[277485671-285031455] \\
& \mathrm{u}_{7}=[285031456-292577240] .
\end{aligned}
$$

Dengan nilai tengah dari masing - masing selang tersebut adalah 243529638; 251075423; 258621208; 266166993; $273712778 ; 281258563 ; 288804348$.

Himpunan fuzzy yang terbentuk adalah sebagai berikut,

$\mathrm{A}_{1}=1 / \mathrm{u}_{1}+0.5 / \mathrm{u}_{2}+0 / \mathrm{u}_{3}+0 / \mathrm{u}_{4}+0 / \mathrm{u}_{5}+0 / \mathrm{u}_{6}+0 / \mathrm{u}_{7}$

$\mathrm{A}_{2}=0.5 / \mathrm{u}_{1}+1 / \mathrm{u}_{2}+0.5 / \mathrm{u}_{3}+0 / \mathrm{u}_{4}+0 / \mathrm{u}_{5}+0 / \mathrm{u}_{6}+0 / \mathrm{u}_{7}$

$\mathrm{A}_{3}=0 / \mathrm{u}_{1}+0.5 / \mathrm{u}_{2}+1 / \mathrm{u}_{3}+0.5 / \mathrm{u}_{4}+0 / \mathrm{u}_{5}+0 / \mathrm{u}_{6}+0 / \mathrm{u}_{7}$

$\mathrm{A}_{4}=0 / \mathrm{u}_{1}+0 / \mathrm{u}_{2}+0.5 / \mathrm{u}_{3}+1 / \mathrm{u}_{4}+0.5 / \mathrm{u}_{5}+0 / \mathrm{u}_{6}+0 / \mathrm{u}_{7}$

$\mathrm{A}_{5}=0 / \mathrm{u}_{1}+0 / \mathrm{u}_{2}+0 / \mathrm{u}_{3}+0.5 / \mathrm{u}_{4}+1 / \mathrm{u}_{5}+0.5 / \mathrm{u}_{6}+0 / \mathrm{u}_{7}$

$\mathrm{A}_{6}=0 / \mathrm{u}_{1}+0 / \mathrm{u}_{2}+0 / \mathrm{u}_{3}+0 / \mathrm{u}_{4}+0.5 / \mathrm{u}_{5}+1 / \mathrm{u}_{6}+0.5 / \mathrm{u}_{7}$

$\mathrm{A}_{7}=0 / \mathrm{u}_{1}+0 / \mathrm{u}_{2}+0 / \mathrm{u}_{3}+0 / \mathrm{u}_{4}+0 / \mathrm{u}_{5}+0.5 / \mathrm{u}_{6}+1 / \mathrm{u}_{7}$.

Dengan variabel linguistiknya masing - masing adalah sangat sangat sedikit, sangat sedikit, sedikit, banyak, sangat banyak, sangat sangat banyak, sangat sangat sangat banyak.

Kemudian, dari selang yang telah terbentuk tersebut, data akan dikelompokkan ke dalam selang yang sesuai. Hal ini yang dinamakan proses fuzzified, mengubah data dalam himpunan crisp menjadi himpunan fuzzy. Hasilnya berupa nilai linguistik tiap data. Setelah itu baru dibentuk FLR $A_{i} \rightarrow A_{j}$, dimana $A_{i}$ sebagai nilai linguistik dari data sekarang dan berada pada left hand side (LHS), serta $A_{j}$ sebagai nilai linguistik dariwaktu selanjutnya dan berada 
pada right hand side (RHS). Hasil dari proses tersebut ditampilkan seperti pada tabel dengan nilai fuzzified dan FLR dibentuk dalam bentuk nilai indeks untuk mewakili $i$ dan $j$.

Tabel 3.

Hasil dalam proses fuzzifikasi dan pembentukan FLR Reguler R-1/450 V

\begin{tabular}{ccccc}
\hline \hline & & & \multicolumn{2}{c}{ FLR } \\
\cline { 4 - 5 } Tahun/Bulan & $\begin{array}{c}\text { Aktual } \\
(\mathrm{kWh})\end{array}$ & Fuzzified & LHS & RHS \\
\hline $2013 / 01$ & 263327410 & 3 & $*$ & $*$ \\
$2013 / 02$ & 260156975 & 3 & 4 & 3 \\
$2013 / 03$ & 242787194 & 1 & 3 & 1 \\
. &. &. &. &. \\
. &. &. &. &. \\
. &. &. &. &. \\
$2016 / 10$ & 279940934 & 6 & 5 & 6 \\
$2016 / 11$ & 271482996 & 5 & 6 & 5 \\
$2016 / 12$ & 278690972 & 6 & 5 & 6 \\
$2017 / 01$ & 275072829 & 5 & 6 & 5 \\
$2017 / 02$ & 242951378 & 1 & 5 & 1 \\
$2017 / 03$ & 271771199 & 5 & 1 & 5 \\
\hline \hline
\end{tabular}

Selanjutnya, data FLR akan dikelompokkan menjadi FLRG dengan mengelompokkan kedalam nilai LHS yang sama, LHS berisi $A_{i}$ dan RHS berisi $A_{j}$. Hasil dari proses pembentukan FLRG ditampilkan seperti pada tabel dengan hasil FLRG dibentuk dalam bentuk nilai indeks untuk mewakili $i$ dan $j$.

Tabel 4.

Hasil dalam proses fuzzifikasi dan pembentukan FLRG Reguler R-1/450 V

\begin{tabular}{cl}
\hline \hline \multicolumn{1}{c}{ FLRG } \\
\hline LHS & \multicolumn{1}{c}{ RHS } \\
1 & $4,3,4,5$ \\
2 & 1 \\
3 & $1,4,2,5,5,5,5$ \\
4 & $3,3,4,5,4,5,3,6,4,5,6,3,6$ \\
5 & $4,4,4,5,5,5,1,4,5,6,4,6,6,1$ \\
6 & $6,3,4,6,3,6,7,5,5,5$, \\
7 & 6 \\
\hline \hline
\end{tabular}

Tahap setelahnya adalah pembobotan. Sebelum itu, dari hasil FLRG tabel 5, harus didapatkan nilai indeks yang sesuai dengan kemungkinan nilai indeks yang terjadi seperti pada tabel 1. Dan hasilnya adalah sebagai berikut :

nilai indeks bobot $A_{1}=[0]$

nilai indeks bobot $\mathrm{A}_{2}=[0]$

nilai indeks bobot $\mathrm{A}_{3}=[0]$

nilai indeks bobot $\mathrm{A}_{4}=\left[\begin{array}{lll}3 & 4 & 5\end{array}\right]$

nilai indeks bobot $A_{5}=\left[\begin{array}{lll}4 & 5 & 6\end{array}\right]$

nilai indeks bobot $\mathrm{A}_{6}=\left[\begin{array}{lll}6 & 7 & 5\end{array}\right]$

nilai indeks bobot $\mathrm{A}_{7}=[0]$

Kemudian, dilakukan perhitungan pembobotan dengan persamaan (6). Hasilnya adalah matriks pembobotan $\boldsymbol{W}\left(A_{i}\right)$ sebagai berikut,

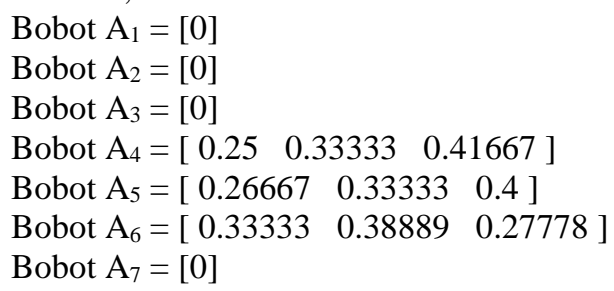

Dari bobot yang telah didapatkan tersebut, selanjutnya dilakukan proses defuzzifikasi, yaitu dengan mendapatkan nilai matriks defuzzifikasinya menggunakan persamaan (7). Matriks defuzzifikasi ini digunakan untuk mengembalikan nilai linguistik pada data FLRG. Hasilnya seperti berikut,

$\mathrm{M} \mathrm{A}_{1}=$ tidak terdapat matriks defuzzifikasi
$\mathrm{M} \mathrm{A}_{2}=$ tidak terdapat matriks defuzzifikasi

$\mathrm{M} \mathrm{A}_{3}=$ tidak terdapat matriks defuzzifikasi

$\mathrm{M} \mathrm{A}_{4}=\left[\begin{array}{lll}258621208 & 266166993 & 273712778\end{array}\right]$

$\mathrm{M} \mathrm{A}_{5}=\left[\begin{array}{llll}266166993 & 273712778 & 281258563\end{array}\right]$

$\mathrm{M} \mathrm{A}_{6}=\left[\begin{array}{lll}281258563 & 288804348 & 273712778\end{array}\right]$

$\mathrm{M} \mathrm{A}_{7}=$ tidak terdapat matriks defuzzifikasi

Hasil tersebut digunakan untuk menghitung nilai peramalan dengan menggunakan persamaan (8) dan menggunakan dua aturan yang berlaku seperti pada poin 2.6.6. Dimana, jika tidak terdapat bobot yang sesuai pada FLRG, maka nilai peramalan sama dengan rata-rata dari nilai tengah interval pada nilai linguistic time series. Selain itu, akan digunakan persamaan (8) sebagai nilai peramalan. Hasilnya seperti berikut,

Nilai Peramalan dari $A_{1}$ adalah 266166993

Nilai Peramalan dari $A_{2}$ adalah 266166993

Nilai Peramalan dari $A_{3}$ adalah 266166993

Nilai Peramalan dari $\mathrm{A}_{4}$ adalah 267424621

Nilai Peramalan dari $A_{5}$ adalah 274718879

Nilai Peramalan dari $A_{6}$ adalah 282096979

Nilai Peramalan dari $A_{7}$ adalah 266166993.

Kemudian dilanjutkan dengan perhitungan hasil akhir ramalan menggunakan beda pertama dari data sebenarnya, seperti pada persamaan (9). Sehingga, hasil akhir peramalan dirumuskan seperti pada persamaan (10). Hasilnya seperti berikut,

Tabel 5.

Nilai ramalan dan hasil akhir ramalan dari pemakaian $\mathrm{kWh}$ listrik Reguler R-1/450 V.

\begin{tabular}{ccccc}
\hline \hline $\begin{array}{c}\text { Data } \\
\text { Aktual } \\
(\mathrm{kWh})\end{array}$ & Fuzz & $\begin{array}{c}\text { Nilai } \\
\text { Ramalan } \\
(\mathrm{kWh})\end{array}$ & Diff $(\mathrm{kWh})$ & $\begin{array}{c}\text { Hasil } \\
\text { Ramalan } \\
\text { Akhir }(\mathrm{kWh})\end{array}$ \\
\hline 263327410 & 4 & $*$ & $*$ & $*$ \\
260156975 & 3 & 267424621 & -3170435 & 264254186 \\
242787194 & 1 & 266170000 & -17369781 & 248800000 \\
265038624 & 4 & 266170000 & 22251430 & 288420000 \\
262302763 & 3 & 267424621 & -2735861 & 264688760 \\
. &. &. &. &. \\
. &. &. &. &. \\
279940934 & 6 & 274718879 & 7392300 & 282111179 \\
271482996 & 5 & 282096979 & -8457938 & 273639041 \\
278690972 & 6 & 274718879 & 7207976 & 281926855 \\
275072829 & 5 & 282096979 & -3618143 & 278478836 \\
242951378 & 1 & 274718879 & -32121451 & 242597428 \\
271771199 & 5 & 266170000 & 28819821 & 294990000 \\
\hline \hline
\end{tabular}

Dari hasil data training tersebut didapatkan nilai MAPE sebesar $1.9562 \%$. Dan bentuk dari grafik perbandingan antara data sebenarnya dengan hasil akhir ramalan adalah sebagai berikut,

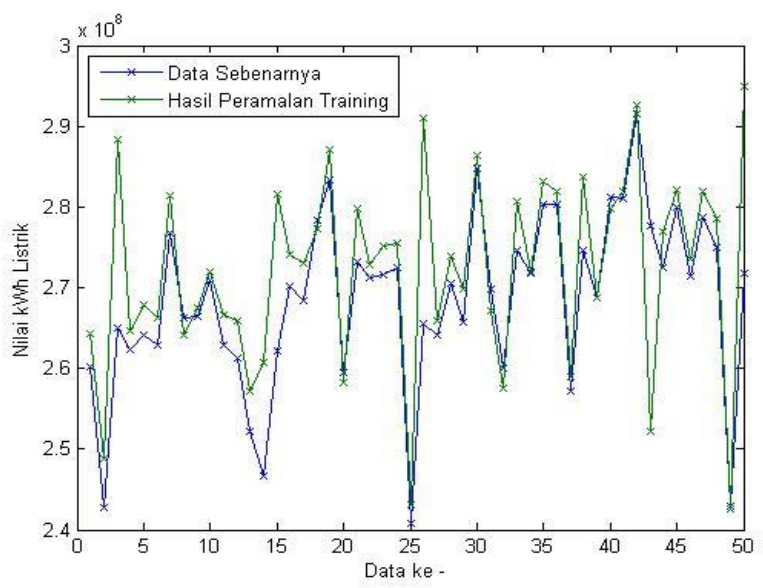

Gambar 2. Plot data training Reguler R-1/450 V. 
Dan hasil untuk prediksi biaya pemakaiannya adalah sebagai berikut,

Tabel 6.

Prediksi biaya pemakaian kWh listrik Reguler R-1/450 V dari data training Hasil Akhir Ramalan $\quad$ Prediksi Biaya Pemakaian kWh Listrik

\begin{tabular}{cc}
$\begin{array}{c}\text { Hasil Akhir Ramalan } \\
(\mathrm{kWh})\end{array}$ & $\begin{array}{c}\text { Prediksi Biaya Pemakaian kWh Listrik } \\
\text { (Rupiah) }\end{array}$ \\
\hline 264254186 & $109,670,000,000$ \\
248800000 & $103,250,000,000$ \\
288420000 & $119,690,000,000$ \\
$\cdot$ & $\cdot$ \\
$\cdot$ & $\cdot$ \\
278478836 & $115,570,000,000$ \\
242597428 & $100,680,000,000$ \\
294990000 & $122,420,000,000$ \\
\hline \hline
\end{tabular}

Kemudian, langkah selanjutnya yang dilakukan adalah pengujian dengan menggunakan data testing yang berjumlah 12 data. Awalnya, dilakukan proses peramalan $F(t+n)$ dengan asumsi awal nilai hasil akhir ramalan $F(t)$ sama dengan hasil akhir ramalan $F(t+1)$. Setelah itu untuk mendapatkan $F(t+n)$, dimana $n=2$, diasumsikan $F(t+1)$ merupakan data yang telah terjadi dan nilai dari $F(t+1)$ digabung dengan seluruh data time series sebelumnya, yang kemudian dilakukan proses yang sama mulai proses fuzzifikasi sampai dengan perhitungan hasil akhir ramalan. Dan hal tersebut berulang sampai dengan input nilai $n$ (jumlah periode ramalan bulan selanjutnya) terpenuhi. Hasil dari pengujian data testing adalah sebagai berikut,

Tabel 7.

Hasil akhir ramalan dan prediksi biaya pemakaian kWh listrik Reguler R$1 / 450 \mathrm{~V}$ dari data testing.

\begin{tabular}{cccc}
\hline \hline Tahun/Bulan & $\begin{array}{c}\text { Data Aktual } \\
(\mathrm{kWh})\end{array}$ & $\begin{array}{c}\text { Hasil Akhir } \\
\text { Ramalan }(\mathrm{kWh})\end{array}$ & $\begin{array}{c}\text { Prediksi Pemakaian } \\
(\text { Rupiah })\end{array}$ \\
\hline $2017 / 04$ & 266468544 & 294990000 & $122,420,000,000$ \\
$2017 / 05$ & 276587094 & 292430000 & $121,360,000,000$ \\
$2017 / 06$ & 281122815 & 265311174 & $110,100,000,000$ \\
$2017 / 07$ & 282751078 & 240760000 & $99,914,000,000$ \\
$2017 / 08$ & 273737673 & 244660000 & $101,530,000,000$ \\
$2017 / 09$ & 266235827 & 271771199 & $112,790,000,000$ \\
$2017 / 10$ & 280363651 & 294990000 & $122,420,000,000$ \\
$2017 / 11$ & 272872078 & 292430000 & $121,360,000,000$ \\
$2017 / 12$ & 276317300 & 265311174 & $110,100,000,000$ \\
$2018 / 01$ & 272310141 & 240760000 & $99,194,000,000$ \\
$2018 / 02$ & 244220157 & 244660000 & $101,530,000,000$ \\
$2018 / 03$ & 270886247 & 271771199 & $112,790,000,000$ \\
\hline \hline
\end{tabular}

Dari hasil data testing tersebut didapatkan nilai MAPE sebesar $6.5055 \%$. Dan bentuk dari grafik perbandingan antara data sebenarnya dengan hasil akhir ramalan adalah sebagai berikut,

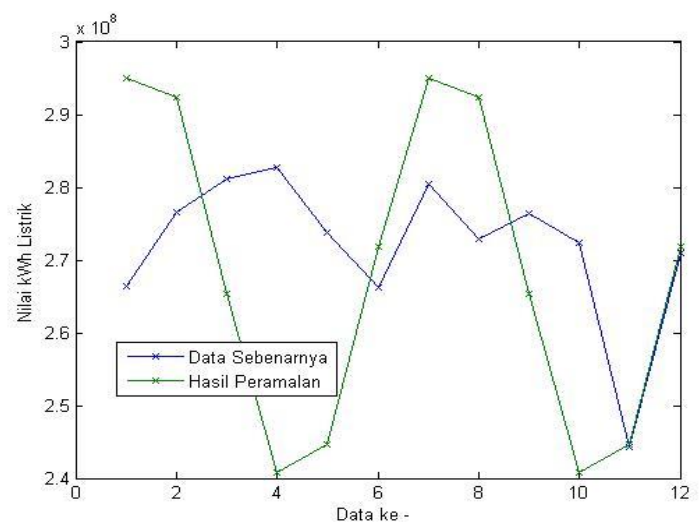

Gambar 3. Perbandingan antara data sebenarnya dengan hasil akhir ramalan.
1. Perbandingan Nilai MAPE Per Jenis Golongan Tarif Rumah Tangga

Dari hasil pengujian metode fuzzy time series sebagai metode peramalan dengan menggunakan data pemakaian $\mathrm{kWh}$ listrik per jenis golongan tarif rumah tangga yang dibagi latih (training) sebanyak $80 \%$ dari data keseluruhan dan data uji (testing) sebanyak 20\% dari data keseluruhan, akan dilakukan perbandingan nilai MAPE per jenis golongan tarif rumah tangga. Perbandingan ini dilakukan agar diketahui sejauh mana metode fuzzy time series ini dapat digunakan dengan baik sebagai metode peramalan dengan melihat nilai kesalahannya (error).

Hasil perbandingan akan ditampilkan dalam tabel berikut,

Tabel 8.

Perbandingan nilai MAPE pada data training jenis golongan tarif reguler

\begin{tabular}{lc}
\hline \multicolumn{1}{c}{ Jenis Golongan Tarif } & Nilai MAPE $(\%)$ \\
\hline R-1/450 VA & 1.9562 \\
R-1/900 VA & 23.6841 \\
R-1/900 VA RTM & 3.4495 \\
R-1/1.300 VA & 2.1325 \\
R-1/2.200 VA & 2.5295 \\
R-2/3.500 VA s.d. 5.500 VA & 2.9609 \\
R-3/6.600 VA Ke Atas & 1.8107 \\
\hline \hline
\end{tabular}

Dari hasil tersebut, terlihat bahwa nilai MAPE terbesar pada data jenis golongan tarif R-1/900 VA. Dari pembahasan sebelumnya, hal itu terjadi karena data yang digunakan terlalu sedikit, serta terdapat kenaikan data atau penurunan data yang sangat signifikan.Hal itu menyebabkan kurangnya penyebaran data pada interval lainnya dan membuat hasil akhir peramalan sangat jauh dari dari data sebenarnya.

Tabel 9.

Perbandingan nilai MAPE pada data testing jenis golongan tarif reguler

\begin{tabular}{lc}
\hline \hline Jenis Golongan Tarif & Nilai MAPE $(\%)$ \\
\hline R-1/450 VA & 6.5055 \\
R-1/900 VA & 5.9852 \\
R-1/900 VA RTM & 11.7686 \\
R-1/1.300 VA & 29.1428 \\
R-1/2.200 VA & 25.3456 \\
R-2/3.500 VA s.d. 5.500 VA & 16.001 \\
R-3/6.600 VA Ke Atas & 4.7755 \\
\hline \hline
\end{tabular}

Dari Tabel 9, dapat terlihat bahwa metode fuzzy time series sangat cocok untuk data pemakaian $\mathrm{kWh}$ listrik jenis golongan tariff R-3/3.600 VA ke atas, dikarenakan MAPE bernilai kurang dari lima persen, atau dapat dikatakan untuk metode fuzzy time series merupakan metode yang baik untuk meramalkan data tersebut. Dan untuk nilai MAPE pada jenis golongan tarif R-1/1.300 VA dan R-1/2.200 VA bernilai besar, dikarenakan ada beberapa data pada hasil akhir peramalan $F(t)$ yang nilainya sangat jauh dari nilai sebenarnya, sehingga membuat nilai dari hasil akhir peramalan $F(t+n)$ jauh dari nilai dari data sebenarnya.

Tabel 10.

Perbandingan nilai MAPE pada data training jenis golongan tarif pra bayar

\begin{tabular}{lc}
\hline \hline Jenis Golongan Tarif & Nilai MAPE $(\%)$ \\
\hline R-1/450 VA & 12.1602 \\
R-1/900 VA & 30.3309 \\
R-1/900 VA RTM & 12.6567 \\
R-1/1.300 VA & 9.9104 \\
R-1/2.200 VA & 6.9662 \\
R-2/3.500 VA s.d. 5.500 VA & 9.2251 \\
R-3/6.600 VA Ke Atas & 11.7488 \\
\hline \hline
\end{tabular}

Dari hasil perbandingan pada Tabel 10, dapat terlihat bahwa nilai MAPE terbesar terdapat pada data jenis golongan tarif R-1/900 VA, hal tersebut sama halnya dengan data jenis golongan tarif reguler R-1/900 VA seperti pada 
tabel 8. Hal tersebut juga terjadi karena, terdapat kenaikan data atau penurunan data yang sangat signifikan yang menyebabkan pula penyebaran data pada interval lainnya kurang.

Tabel 11.

Perbandingan nilai MAPE pada data testing jenis golongan tarif pra bayar

\begin{tabular}{lc}
\hline \hline Jenis Golongan Tarif & Nilai MAPE $(\%)$ \\
\hline R-1/450 VA & 11.3923 \\
R-1/900 VA & 10.4318 \\
R-1/900 VA RTM & 31.9158 \\
R-1/1.300 VA & 18.0645 \\
R-1/2.200 VA & 10.6514 \\
R-2/3.500 VA s.d. 5.500 VA & 13.9601 \\
R-3/6.600 VA Ke Atas & 17.2947 \\
\hline \hline
\end{tabular}

Untuk Tabel 11, dapat terlihat untuk keseluruhan data nilai MAPE, rata-rata bermilai antara $10 \%$ sampai dengan $20 \%$. Dari hal tersebut dapat dikatakan peramalan dengan metode fuzzy time series tidak cukup baik untuk data kelompok rumah tangga golongan tariff pra bayar. Seperti pada pembahasan sebelumnya, pada golongan tariff pra bayar ini, terdapat kenaikan data atau penurunan data yang sangat signifikan, sehingga membuat nilai hasil akhir peramalan sangat jauh dari data sebenarnya.

2. Hasil Peramalan untuk Data Keseluruhan dalam Periode $(t+n)$

Pada tahap ini, dilakukan peramalan dengan mengolah keseluruhan data per jenis golongan tarif, sehingga perlu diinputkan nilai dari $n$ sebagai periode ramalan yang ingin diketahui nilai ramalannya. Dan untuk inputan nilai $n$ dalam periode bulan, diberikan $n=10$, sehingga nilai permalannya mulai bulan April 2018 sampai dengan bulan Januari 2019. Dari pembahasan sebelumnya, diambil 1 contoh bahasan, sehingga hasil yang ditampilkan pada bagian ini adalah golongan tarif reguler R-1/450 V. Hasil dari peramalan untuk periode $(t+n)$, sebagai berikut :

$$
\text { Tabel } 12 .
$$

Tabel nilai peramalan pada $(t+10)$ untuk jenis golongan tarif reguler $\mathrm{R}$ $1 / 450 \mathrm{~V}$

\begin{tabular}{ccc}
\hline \hline $\mathrm{n}$ & Nilai Ramalan kWh Listrik & $\begin{array}{c}\text { Prediksi Biaya Pemakaian } \\
\text { (Rupiah) }\end{array}$ \\
\hline 1 & 292830000 & $121,530,000,000$ \\
2 & 297500000 & $123,460,000,000$ \\
3 & 273790000 & $113,620,000,000$ \\
4 & 245420638 & $101,850,000,000$ \\
5 & 245410000 & $101,840,000,000$ \\
6 & 269110000 & $111,680,000,000$ \\
7 & 292833086 & $121,530,000,000$ \\
8 & 290400000 & $120,520,000,000$ \\
9 & 288970000 & $119,920,000,000$ \\
10 & 267692976 & $111,090,000,000$ \\
\hline \hline
\end{tabular}

\section{KESIMPULAN}

Dari hasil pembahasan yang telah disajikan dapat disimpulkan:

Dari hasil pembahasan yang telah disajikan pada bab sebelumnya, dapat disimpulkan bahwa:

1. Nilai hasil akhir peramalan peramalan dengan menggunakan fuzzy time series, rata - rata pada waktu ke $(t+1)$ lebih mendekati nilai sebenarnya daripada nilai hasil akhir peramalan waktu ke - $(t+n)$, untuk nilai $n=2,3,4$, $\ldots$, N. Nilai dari peramalan waktu ke - $n$ atau yang dinamakan nilai $F(t+n)$ untuk $n=2,3,4, \ldots, \mathrm{N}$, merupakan nilai gabungan antara nilai $F(t+1)$ dan juga nilai error dari $F(t+1)$. Akan tetapi, nilai ramalan juga bergantung pada penetapan nilai $D_{1}$ dan $D_{2}$ pada tahap pendefinisian universe of discourse.

2. Dari pembahasan perbandingan nilai MAPE, dapat dilihat bahwa MAPE data training terbesar pada data jenis golongan tarif R-1/900 VA, baik untuk tarif reguler maupun prabayar. Hal tersebut terjadi, karena data yang digunakan terlalu sedikit, serta terdapat kenaikan data atau penurunan data yang sangat signifikan pada data pemakaian kWh listrik bulanan golongan tarif rumah tangga. Sehingga, menyebabkan kurangnya penyebaran data pada interval lainnya yang mengakibatkan hasil akhir peramalan sangat jauh dari nilai data sebenarnya. Metode fuzzy time series sangat cocok untuk data pemakaian $\mathrm{kWh}$ listrik jenis golongan tariff R-3/3.600 VA ke atas, dikarenakan MAPE bernilai kurang dari lima persen, atau dapat dikatakan untuk metode fuzzy time series merupakan metode yang baik untuk meramalkan data tersebut.

3. Dapat ditemukan nilai prediksi jumlah rupiah penjualan energi listrik per $\mathrm{kWh}$ dengan cara mengalikan hasil akhir ramalan pemakaian $\mathrm{kWh}$ listrik dengan tarif dasar listrik yang berlaku tiap golongan tarif rumah tangga.

\section{DAFTAR PUSTAKA}

[1] Ditjen Ketenagalistrikan KESDM, "Statistik Ketenaga-listrikan 2017," Jakarta, 2016.

[2] Republika Surabaya, "Konsumsi Listrik Masyarakat Jatim Meningkat 15,2 Persen," 2017. [Online]. Available: http://nasional.republika.co.id/berita/nasional/daerah/17/10/27/oy gprw423-konsumsi-listrik-masyarakat-jatim-naik-152-persen.

[3] A. Nugroho and B. Winardi, "Peramalan Kebutuhan Energi Listrik Tahun 2006-2015 Menggunakan Metode Gabungan Dengan Pemrograman Visual Basic," Transmisi, vol. 10, no. 4, pp. $179-184$, Nov. 2012

[4] Menteri Energi dan Sumber Daya Mineral Republik Indonesia, "Peraturan Menteri Energi dan Sumber Daya Mineral Republik Indonesia, nomor 28 tahun 2016," 2016.

[5] M. H. Lee, R. Efendi, and Z. Ismail, "Modified Weighted for Enrollment Forecasting Based on Fuzzy Time Series," 2009.

[6] PT. PLN (Persero) Distribusi Jawa Timur, "Buku Statistik PT. PLN (Persero) Distribusi jawa Timur Tahun 2016," Surabaya, 2017.

[7] R. Efendi, Z. Ismail, and M. M. Deris, "A new linguistic outsample approach of fuzzy time series for daily forecasting of Malaysian electricity load demand," Appl. Soft Comput., vol. 28, pp. 422-430, Mar. 2015.

[8] Kusumadewi, Aplikasi Logika Fuzzy untuk pendukung keputusan. Yogyakarta: Graha Ilmu, 2013

[9] Q. Song and B. S. Chissom, "Forecasting enrollments with fuzzy time series - Part I," Fuzzy Sets Syst., vol. 54, no. 1, pp. 1-9, Feb. 1993.

[10] Y. Ekananta, L. Muflikhah, and C. Dewi, "Penerapan Metode Average-Based Fuzzy Time Series Untuk Prediksi Konsumsi Energi Listrik Indonesia," J. Pengemb. Teknol. Inf. dan Ilmu Komput., vol. 2, no. 3, pp. 1283-1289, 2018.

[11] H.-J. Zimmermann, "Fuzzy set theory," Wiley Interdiscip. Rev. Comput. Stat., vol. 2, no. 3, pp. 317-332, May 2010.

[12] M. L. Tauryawati and M. I. Irawan, "Perbandingan Metode Fuzzy Time Series Cheng dan Metode Box-Jenkins untuk Memprediksi IHSG," J. Sains dan Seni ITS, vol. 3, no. 2, pp. A34-A39, Sep. 2014.

[13] E. Stellwagen, "A Guide to Forecast Error Measurement Statistics and How to Use Them," 2017. [Online]. Available: https://www.forecastpro.com/Trends/forecasting101 August2011. html.

[14] R. Anggrainingsih, G. R. Aprianto, and S. W. Sihwi, "Time series forecasting using exponential smoothing to predict the number of website visitor of Sebelas Maret University," in 2015 2nd International Conference on Information Technology, Computer, and Electrical Engineering (ICITACEE), 2015, pp. 14-19. 